\title{
8. How different was Victoria? Aboriginal 'protection' in a comparative context
}

\author{
Jessie Mitchell and Ann Curthoys
}

Scholars of settler colonial governance in Victoria have tended to characterise the colony as distinctive. It was, most agree, shaped by unusually intensive efforts to govern, survey, 'civilise' and control Aboriginal people, rather than to destroy or simply neglect them, although the latter certainly occurred too. ${ }^{1}$ Here, we wish to scrutinise the idea of Victorian exceptionalism, focusing on the late 1850s and early 1860s, the years shortly after the achievement of responsible government in 1856. With responsible government, Britain lost control over Aboriginal policy, and, just as importantly, British humanitarian societies lost their lines of direct influence on policy. In this period, then, we can trace the beginnings of Aboriginal policy as colonial politicians devised it under the new system of responsible government.

This era provides an especially interesting opportunity to consider how different Victoria really was in relation to Aboriginal affairs. One distinctive aspect of Victoria's history in the late 1850s and early 1860s was a series of significant reports and policies produced concerning Aboriginal 'protection'. While several scholars have considered them, ${ }^{2}$ they rarely note that at the same time South Australia, New South Wales and the new colony of Queensland were also conducting inquiries into matters of Aboriginal policy. The reports emanating from these four colonies were markedly different from each other in purpose, tone, content and findings. Although prompted by specific local incidents and concerns, it is striking that they appeared at about the same timeduring the first few years of responsible settler government and after a common neglect within the colonies of Aboriginal affairs for most of the 1850 s as political structures were refashioned. All were marked in different ways by the legacies of dispossession and the frontier, and all addressed colonists' capacity and responsibility to govern - or control - native peoples in this new self-governing era. This chapter discusses these reports in a comparative context, asking how and why they differed, and what they had in common. It also looks at the

\footnotetext{
1 On physical destruction, see Lyndall Ryan, 'Settler massacres on the Port Phillip frontier, 1836-1851', Journal of Australian Studies 34(3), 2010: 257-273.

2 For example, Bain Attwood, Rights for Aborigines, Allen \& Unwin, Sydney, 2003; Diane Barwick, Rebellion at Coranderrk, Laura E Barwick and Richard E Barwick (eds), Aboriginal History Inc., Canberra 1998; Richard Broome, Aboriginal Victorians: A History Since 1800, Allen \& Unwin, Sydney, 2005.
} 
remaining two Australian colonies - Tasmania and Western Australia - asking why there were no similar formal reviews of Aboriginal policy in those two colonies at this time, and how they, too, resembled or differed from the situation in Victoria.

\section{Victoria}

By the end of the 1850s, most Victorian colonists no longer faced any real threat to their lives or property from Aboriginal people. The rapid seizure of land, the successful bid for government separate from New South Wales, the massive influx of wealth and migration during the gold rush, the acquisition of responsible government, and the comparatively small size of the colony, all meant that by the late 1850 s it was relatively easy for colonists to put Aboriginal dispossession behind them. Indeed, thanks to the district's rapid population change, most Victorians had never personally experienced the struggles over Aboriginal land. The Aboriginal population was a little over 2,000, a rapid decline from an estimated population of between 10,000 and 15,000 in 1835. ${ }^{3}$ The old Protectorate, established on instructions from the British government in 1839, had been finally disbanded in 1849, though William Thomas remained as Guardian for Aborigines from 1850 until his death in 1867. ${ }^{4}$ A subsequent attempt to set up a Moravian mission was also set aside, though a second attempt would begin in $1859 .^{5}$

Nonetheless, a certain inclination towards philanthropy did exist. This was partly a legacy of the old Protectorate and the small efforts of Moravian missionaries in the 1850s. It was also a product of the significant changes in the cultural and social climate in the colony. The new prosperity and mass migration had led to the growth of networks of educated men in Victoria, who aspired to promote cultural progress and scientific enlightenment. The era saw the establishment of scientific societies, plans for a university and a public library, and the rise of public intellectuals such as Ferdinand von Mueller and The Argus editor Edward Wilson. ${ }^{6}$ In a newly prosperous colony where settlers were used to asserting

3 See Len R Smith, 1980, The Aboriginal Population of Australia, Australian National University Press, Canberra, 1980, cited by the Australian Bureau of Statistics (ABS), cat.no. 3105.0.65.001, Australian Historical Population Statistics, Table 8, Minimum estimates of the Indigenous population, states and territories, 17881971.

4 Liz Reed, 'Rethinking William Thomas, "friend" of the Aborigines', Aboriginal History 28, 2004: 87.

5 Jane Lydon, Fantastic Dreaming: The Archaeology of an Aboriginal Mission, Altamira, New York, 2009; Robert Kenny, The Lamb Enters the Dreaming: Nathanael Pepper and the Ruptured World, Scribe, Melbourne, 2007.

6 Don Garden, Victoria: A History, Nelson, Melbourne, 1984: 98; Linden Gillbank, 'A paradox of purposes: Acclimatization origins of the Melbourne Zoo', in RJ Hoage and William A Deiss (eds), New Worlds, New 
themselves as successful, free entrepreneurs, proud of their achievements and confident to govern themselves, the idea of a more charitable Aboriginal policy began to gather support.

One of the key movers for a new approach was Thomas McCombie, a writer, merchant and member of the Legislative Council. In 1858, McCombie released The History of the Colony of Victoria, where he acknowledged the violence of early colonisation but depicted it as securely in the past, while praising the colonising zeal of what he termed the Anglo-Saxon race. At the antipodes, McCombie said, colonists would build 'a second happy England'. ${ }^{7}$ While researching his book, however, McCombie became concerned about Aboriginal circumstances, and in October 1858, he succeeded in setting up a select committee in the Legislative Council to investigate the condition of Aboriginal people in the colony. His initiative was vital to the formation and conduct of the committee - according to Diane Barwick, McCombie was the only committee member who attended all the hearings and a key figure in drafting the final report. ${ }^{8}$ The committee investigated Aboriginal numbers, ages, health, education and access to land and resources, as well as including lengthy ethnographic material about linguistics, craniology, diet, dress, ceremonies, funerals and marriage. The report also included questions about Indigenous people's own forms of government, asking whether authority was monarchical, democratic or priestly, how it was conferred, whether a class system existed, and how laws and punishments were enforced. ${ }^{9}$

The emphasis on ethnography - with questions adapted from the British Association for the Promotion of Science and the Ethnographical Society of Paris - pointed towards the kind of governance of Aboriginal people that some Victorian colonists hoped to develop. This body of Victoria's leading settlers, reporting back to parliament and the public, sought to construct themselves as an educated, cosmopolitan community, linked to European scientific trends and safely separate from and superior to the people they documented. The report did not acknowledge directly any Indigenous witnesses, and despite the committee's concern for Indigenous people, there was something ominous about its eagerness to build its own expertise. Echoing sentiments expressed by the British Association, the writers remarked upon:

\footnotetext{
Animals: From Menagerie to Zoological Park in the Nineteenth Century, John Hopkins University Press, Baltimore, 1996: 74; Christopher Lever, They Dined on Eland: The Story of the Acclimatisation Society, Quiller Press, London, 1992: 107.

7 Thomas McCombie, The History of the Colony of Victoria, from its settlement to the death of Sir Charles Hotham, Sands and Kenny, Melbourne, 1858: 41. Also Fergus Farrow, 'McCombie, Thomas (1819-1869)', Australian Dictionary of Biography, Melbourne University Press, Carlton, 1974: 14-17, 40, 132-133.

8 Barwick, Rebellion at Coranderrk: 37-38.

9 Report of the Select Committee of the Legislative Council on the Aborigines, Together with the Proceedings of Committee, Minutes of Evidence, and Appendices', Votes and Proceedings of the Legislative Council of Victoria, Session 1858-59, Vol I.
} 
the irretrievable loss which science must sustain if so large a portion of the human race ... is suffered to perish before many interesting questions of a psychological, physiological, and philological character ... have been investigated. ${ }^{10}$

The idea that Indigenous people were doomed to extinction underlay the committee's whole enterprise. Indeed, McCombie himself had written 14 years earlier that 'within a century the race will be nearly extinct. This seems almost their inevitable fate, and we cannot but deplore it.'11

Perhaps the 'almost' in McCombie's earlier work was significant, for the Select Committee's report that McCombie presented to the Legislative Council in January 1859 demonstrated not only a scientific imperative but also a genuine humanitarian concern. It provided shocking evidence of Indigenous depopulation, and accused the government of neglecting Aboriginal people, abandoning them to poverty, illness, alcoholism and the violence and vices of Europeans. ${ }^{12}$ It recommended greater government intervention, including new reserves for agriculture, pastoralism and missionary work. The result was the establishment the following year of the Central Board Appointed to Watch over the Interests of the Aborigines. It was the first of its kind in the Australian colonies, and there was nothing very similar in Britain's other settler colonies with Aboriginal minorities, in North America and New Zealand. In its early years, the Board focused on rations, clothing, medicine, missionary schooling and agricultural training. Its first two reports acknowledged that colonists had a duty to protect Aboriginal people 'and to a certain extent maintain them', having taken their country. ${ }^{13}$ In 1869, the Aborigines Protection Act 1869 (Vic) extended the system and replaced the Central Board with the more powerful Board for the Protection of Aborigines. There was nothing similar in the other colonies until the 1880s; for at least two decades, Victoria had both the smallest Aboriginal population of any mainland colony and the most comprehensive reserve system. ${ }^{14}$

10 'Report of the Select Committee of the Legislative Council on the Aborigines' (1858-59): 25.

11 Thomas McCombie, 'Adventures of a Colonies, or Godfrey Arabin the Settler', a digital text sponsored by the Australian Cooperative Digitisation Project 1840-1845, prepared from the print edition published by John and Daniel A Darling, London, 1845, no page number.

12 The Argus, 27 January 1859: 7; 'Report of the Select Committee of the Legislative Council on the Aborigines' (1858-59): iii-iv.

13 First Report of the Central Board Appointed to Watch Over the Interests of the Aborigines in the Colony of Victoria, John Ferres, Melbourne, 1861: 5, 11; Second Report of the Central Board Appointed to Watch Over the Interests of the Aborigines in the Colony of Victoria, John Ferres, Melbourne, 1862: 15 (SLV).

14 Richard Broome, Aboriginal Victorians: A History Since 1800, Allen \& Unwin, Sydney, 2005: 126. 


\section{South Australia}

Victoria was beginning to shape a policy of protection and control in a clearly post-invasion context. However, in the other mainland colonies dispossession and frontier violence were ongoing processes. South Australia shared with Victoria a history of missionary and protectorate work amongst Aboriginal people, and indeed a claim to exceptionalism in its relative caring and humanitarian treatment of Aboriginal people. As Robert Foster and Amanda Nettelbeck have shown, this claim was part of South Australia's oft-made portrayal of itself as having an exceptionally civilised character. ${ }^{15}$ South Australians often spoke of their progressive, respectable heritage, reflected in their relatively calm local politics, the absence of a convict system in their region, and their liberal franchise. As in Victoria, there was a perception of a need to govern, as opposed to simply displace and ignore, Indigenous people, but in contrast to Victoria, South Australia still had a large, moving rural frontier and a significant body of pastoralists who sought or depended on Aboriginal labour. Indeed, the colony was perhaps most striking for its mixture of accepting the need for 'protection' and education, supporting Aboriginal employment in the pastoral industry, and continuing dispossession by force in marginal 'frontier' areas.

Controversies over Aboriginal policy in both 'settled' and 'frontier' areas led to the establishment in September 1860 of a Select Committee of the Legislative Council. Its task was to enquire into the condition of Aboriginal people, the cost of existing systems of management and control, and to suggest any changes to that system it deemed expedient. ${ }^{16}$ Powerful pastoralist, banker and politician, John Baker had originally proposed in the legislature a commission of inquiry, seemingly as part of his dispute with missionary George Taplin over Taplin's siting his mission on Crown land at Point Macleay on the Narrung Peninsula, where Baker had extensive pastoral interests. ${ }^{17}$ In the ensuing parliamentary discussion, however, members expressed a variety of views, including Samuel Davenport, the member for Hindmarsh, who aired concerns over Aboriginal wellbeing. The Council agreed that a select committee, which would be necessarily impartial, would be more appropriate. ${ }^{18}$ George Hall, a shipping agent and company director chaired the committee; the other members, in

\footnotetext{
15 Amanda Nettelbeck and Robert Foster, 'Commemorating foundation: a study in regional historical memory', History Australia 7(3), 2010: 53.1-53.18.

16 Report of the Select Committee of the Legislative Council upon "The Aborigines" together with Minutes of Evidence and Appendix', South Australia, Votes and Proceedings, Legislative Council, WC Cox, Adelaide, 1860. 17 Cameron Raynes, 'A Little Flour and a Few Blankets': An Administrative History of Aboriginal Affairs in South Australia, 1834-2000, State Records of South Australia (SRSA), Gepps Cross, 2002: 17; South Australian Advertiser, 8 June 1859: 3.

18 Lew Chinner, 'Aboriginal Administration and Affairs at the time of the 1860 South Australian Legislative Council Select Committee Report on Aborigines', Cabbages and Kings: Selected Essays in History and Australian Studies, vol. 9, 1981: 16-22. http://ura.unisa.edu.au/R/?func=dbin-jump-full\&object_id=unisa25975, see p. 19.
} 
addition to Baker and Davenport, were George Fife Angas, a landowner with an interest in Aboriginal improvement, and George Waterhouse, a businessman who would become premier the following year. In other words, it represented a range of views on Aboriginal policy.

The committee's scope was broad, and it examined 19 witnesses, including missionary Taplin, various figures in the Anglican Church, the secretary of the Aborigines Friends' Association that supported Taplin's mission, police, a prison superintendent, and two Aboriginal (both Moorundee) people from Port Lincoln - a man, Panyarra, and a woman, Parako. Its final report represented the diversity of its membership and perhaps the breadth of its inquiries. It recognised that Aboriginal people had had 'an equitable title to the lands they occupied, and of which they are virtually all dispossessed', and concluded that they had lost much and gained little from British rule, suffering as they were from sickness, hunger, disease, alcohol and social breakdown. Harking back to the original instructions to South Australians, and recalling missionary efforts made in the past, the committee agreed that Indigenous people were entitled to compensation for their loss, and called for a new protectorate and wider rationing systems. ${ }^{19}$ At the same time, the report also insisted that the costs should be borne by leasing to settlers land originally set aside as reserves for Aboriginal use, asserted they were probably doomed as a race, and concluded with a strong argument for child removal if Aboriginal people were ever to be Christianised. ${ }^{20}$

The report did have some results: the office of Chief Protector, which the newly responsible government in 1856 had abolished, was reinstated in 1861, and the ration system expanded, although not on the Victorian scale. ${ }^{21}$ As Robert Foster suggests, the government adopted these measures not only on humanitarian grounds but also as a means to encourage Aboriginal employment, especially in the pastoral industry. Pastoralists had for the first time become aware of the potential of Aboriginal pastoral labour during the preceding decade, when so many European labourers had left for the Victorian gold rushes. As the gold rushes subsided, European labour returned to the settled areas but not to the remote areas in the north and west of the colony where settlers were establishing new pastoral stations. In these areas, with their chronic shortage of European labour, Aboriginal labour became essential. The government had an existing

19 On the idea of compensation in humanitarian discourse in the Australian colonies, see Anne O'Brien, 'Humanitarianism and reparation in colonial Australia', Journal of Colonialism and Colonial History 12(2), 2011. 20 Graham Jenkin, Conquest of the Ngarrindjeri, Rigby, Adelaide, 1979: 84-95; South Australian Advertiser, 31 October 1860: 3; "Report of the Select Committee of the Legislative Council upon "The Aborigines", printed 16 October 1860', in Proceedings of the Parliament of South Australia: 1860, vol. 3, Government Printer, Adelaide, 1860: 2.

21 'Report of the Select Committee of the Legislative Council upon "The Aborigines", printed 16 October 1860'; Robert Foster, 'Rations, coexistence, and the colonisation of Aboriginal labour in the South Australian pastoral industry, 1860-1911', Aboriginal History 24, 2000: 5. 
policy of distributing rations, which had started in the 1840s as a means of humanitarian assistance, a form of compensation for loss of traditional means of subsistence, and a means of exerting control. Now it became, in addition, a means of attracting Aboriginal people to pastoral stations as labourers. ${ }^{22}$ In six years, the new Chief Protector, Dr John Walker, increased the number of ration depots from 14 to 58. In the northern and western pastoral districts, rations were issued not by police, as in the south, but by managers of pastoral stations, as recommended by the 1860 Select Committee. Ration-giving would assist the development of a relationship between pastoralists and Aboriginal people, and thus help draw them into the pastoral industry. ${ }^{23}$ Rations were not, as in the Victorian case, associated with the development of missions and reserves with a protective and educational mission.

Some of the concerns expressed in this South Australian report, especially those to do with the necessity of assisting the destitute, echoed those in the Victorian report of the previous year. This report, however, differed from the Victorian one in several key ways. It displayed no particular interest in Indigenous cultural life, and the South Australian committee members were not interested in setting themselves up as scientific experts. They were far more preoccupied with how to prevent and manage Aboriginal resistance to the spread of settlement, and their report showed a concern, not evident in Victoria, about the extent and nature of judicial and police powers. The report called for protectors to be given powers to stage summary trials in local districts of Indigenous people accused of noncapital offences. Summary justice - which the committee did not recommend extending to Europeans - would cut down on the cost of sending prisoners long distances and end the practice of capturing Aboriginal witnesses and sending them to the cities in chains. ${ }^{24}$ In this context, the report raised the question of whether Indigenous people were British subjects to be treated before the law the same as any other British subject. Crown authorities had always insisted that they were, and settler governments agreed, but the issue had not been resolved in public debate or in local legal practice. ${ }^{25}$ The committee hinted that Aboriginal peoples might be recognised as having distinct societies with a degree of internal sovereignty, and commented that the strict application of British criminal law to the aborigines of this Colony is not in accordance with the principles of equity and justice' ${ }^{26}$

\footnotetext{
22 Foster, 'Rations, coexistence, and the colonisation of Aboriginal labour': 2-5.

23 Foster, 'Rations, coexistence, and the colonisation of Aboriginal labour': 11.

24 Jenkin, Conquest of the Ngarrindjeri: 84-95; South Australian Advertiser, 31 October 1860: 3; 'Report of the Select Committee of the Legislative Council upon “The Aborigines", printed 16 October 1860': 2.

25 See Lisa Ford, Settler Sovereignty: Jurisdiction and Indigenous People in America and Australia, 1788-1836, Harvard University Press, Cambridge, MA, 2010.

26 'Report of the Select Committee of the Legislative Council upon "The Aborigines", printed 16 October $1860^{\prime}: 2$. There is a considerable literature on the question of the application of British criminal law to
} 
The question of summary justice arose again, with greater urgency, the following year. When some Aboriginal men murdered Mary Rainbird and her two children on a farm near Kapunda, South Australia's largest town outside Adelaide, in March 1861, this excited popular outrage, and four Aboriginal men were hanged for the crime in Adelaide gaol. ${ }^{27}$ They were executed there since public hanging had been banned under an Act to Regulate the Execution of Criminals three years earlier. Respectable society had come to see public hanging as an offensive practice, encouraging depravity amongst the lower classes. ${ }^{28}$ However, in the Rainbird case, local newspapers were angry that the authorities had hanged the convicted men where their countrymen could not see them, and soon after, the legislature amended the Act to enable Aboriginal executions to take place where the crime had been committed. ${ }^{29}$ As it turned out, after several public executions in the early 1860s, this law fell into disuse, and the government removed it from the statute books in $1876 .{ }^{30}$ This brief reinstatement of public execution for Aboriginal people in South Australia suggests, nevertheless, that Foucault's narrative in Discipline and Punish of an historical transition from public execution to private incarceration needs modification in a settler-colonial context. Punishment under colonial conditions did not follow any simple timeline. ${ }^{31}$ Orderly and sometimes humanitarian forms of government could and did coexist with the continuing invasion of Aboriginal lands, and with laws and practices that enshrined the values of the frontier.

\section{New South Wales}

Policing the frontier was still in the late 1850s of concern in New South Wales, at least in relation to its northern districts that were not separated to form the colony of Queensland until June 1859. In 1857 and 1858, the NSW Assembly held inquiries into the workings of the Native Mounted Police, a paramilitary body first developed in 1839 in Victoria when it was the Port Phillip District

Aborigines, especially for inter se crimes; see especially Bruce Buchan, The Empire of Political Thought: Indigenous Australians and the Language of Colonial Government, Pickering and Chatto, London, 2008, ch. 4; and Ford, Settler Sovereignty.

27 Alex C Castles and Michael C Harris, Lawmakers and Wayward Whigs: Government and Law in South Australia, 1836-1986, Wakefield Press, Adelaide, 1987: 22; Peter Liddy, The Rainbird Murders, Peacock Publications, Norwood, 1993: 72-83; Cameron Raynes, 'A Little Flour and a Few Blankets': 18; South Australian Advertiser, 29 May 1861: 3.

28 Mark Finnane and John Maguire, 'The uses of punishment and exile: Aborigines in colonial Australia', Punishment and Society 3(2) April 2001: 279-298.

29 Act to amend Act no. 23 of 22nd Victoria intituled 'An Act to Regulate the Execution of Criminals'. May 1861, repealed 38/1876, s. 3,

30 See also John Maguire, 'Judicial violence and the civilising process', Australian Historical Studies 29(111), 1998: 187-209, this material on p. 201.

31 See Amanda Nettelbeck and Robert Foster, 'Colonial Judiciaries, Aboriginal protection and South Australia's policy of punishing "with exemplary severity"', Australian Historical Studies 41(3), 2010: 319-336. 
within New South Wales, and subsequently used to enforce pastoralists' power in the north of the colony. These inquiries each produced a report containing lengthy findings about the size, style and management of the NMP; the report of the second inquiry, which had been prompted by the murders of the Fraser family at Hornet Bank in 1857 and the subsequent retaliatory settler violence, was especially detailed. In contrast to Victoria and South Australia, where the reports had emanated from the more conservative Legislative Councils, these two reports were generated by enquiries in the democratically elected Assembly. Those prompting the inquiries, however, were pastoralists seeking higher levels of government protection for settlers in frontier districts: Gordon Sandeman, member for Moreton Bay and other northern districts, called for the first NMP inquiry, while Darling Downs squatter, Arthur Hodgson, sought the second. Both reports called for the government to expand the force and govern it through stronger and more systematic processes. The first, recommending the expansion and reorganisation of the force, was adopted in full, with little dissent, and its recommendation quickly put into effect. The second, recommending an increase in the number of white troopers, was rejected, largely on the grounds that the necessary expansion of the force had already taken place. ${ }^{32}$

Ethnography and culture played no significant part in these reports, and they displayed little concern for the treatment, safety and future of Indigenous people. ${ }^{33}$ Some northern witnesses took this opportunity to disparage the notion they should be governed from Sydney at all - northern colonists at this time resented southern government and were expressing their desire for independence. ${ }^{34}$ In fact, a number of politicians and commentators in the south supported the northern pastoralists and urged the government either to act harshly to suppress Indigenous resistance or let squatters do it themselves. The key message in both north and south was support, with violence if necessary, for the spread of the pastoralist industry through the north. When the Native Police question moved to Queensland, Aboriginal issues virtually disappeared for some years from government policy and parliamentary debate in New South Wales. There were few voices calling for greater protection, assistance, education or control. There was no government funding to support missionary enterprises, and the government had abolished the long-standing grant to the Wellington Valley mission in 1856. In 1859, some consternation arose in the Assembly, when one member asked whether Aboriginal men could vote. No

\footnotetext{
32 Sydney Morning Herald, 18 August 1858: 5.

33 Moreton Bay Courier, 18 August 1858: 4; New South Wales (NSW) Legislative Assembly, 'Report from the Select Committee on the Native Police Force', 1857: 6, in Various papers of the government of New South Wales, relative to the Aborigines, 1854-62, State Library of Victoria (Rare La Trobe collection); NSW Legislative Assembly, 'Report from the Select Committee on Murders by the Aborigines on the Dawson River', 1858, pp. 5-7, in Various papers of the government of New South Wales, relative to the Aborigines.

34 J. Mitchell, “"The Gomorrah of the Southern Seas": population, separation and race in early colonial Queensland', History Australia 6(3), December 2009: 69.7-69.10.
} 
one knew; Premier Cowper thought they could not, one member said if they could it would be necessary to disqualify them, and the Attorney-General said he would find out, though he never did..$^{35}$ In the end, the debate seems to have subsided into indifference, so secure were colonists in their assumption that responsible government was synonymous with white British manhood. There was little scientific interest in Aboriginal societies in New South Wales during this time, although there were a few men interested in collecting information on Aboriginal languages, notably the travelling missionary, William Ridley. ${ }^{36}$ Some legal assistance continued, but medical assistance was gradually phased out. Prompted by what was possibly the last exchange on Aboriginal matters between a governor in New South Wales and the Secretary of State for the Colonies in Britain in 1859, the Executive Council commented that previous measures to protect and Christianise Aboriginal people had been unsuccessful and it was clear they would never become civilised. ${ }^{37}$ John Robertson, a leading politician and premier during 1860, believed Aboriginal people should be left alone; the colonists had done all they could, to no avail. The only policy was the continuation and expansion of the annual blanket distribution that had operated since the time of Governor Macquarie. Blankets had become essential for many Aboriginal people to survive the winter, but their annual distribution in towns also encouraged contact between Aboriginal people and country police and magistrates, and thus aided population counting and surveillance.

A Victorian-style approach did not come to New South Wales until the early 1880s. It literally crossed the Murray River when Daniel Matthews, a Victorian, established the Maloga mission on the New South Wales side of the river on his private land, selected under the Robertson Land Acts of $1861 .{ }^{38}$ When the mission got into financial trouble and needed government assistance from the late 1870s, Matthews found that he had to appeal to an initially very unresponsive New South Wales government, rather than the closer and more familiar Victorian one. From this circumstance, and Matthews's enormous energy, along with that of another Victorian, John Gribble (later to make his mark in Western Australia), came the formation of the Aborigines Protection Society in New South Wales in 1878. Its campaign for a change in policy was ultimately successful.

35 Votes and Proceedings, NSW Legislative Assembly, 1858-9, volume 1, entry for 17 February 1859; Anna Doukakis, The Aboriginal People, Parliament and 'Protection' in New South Wales 1856-1916, Federation Press, Sydney, 2006: 25.

36 Niel Gunson, 'Ridley, William (1819-1878)', Australian Dictionary of Biography, The Australian National University, 1976, http://adb.anu.edu.au/biography/ridley-william-4477.

37 Doukakis, The Aboriginal People: 148.

38 An Act for Regulating the Alienation of Crown Lands, 18 October 1861 (1861 25 Vic. No 1). 


\section{Queensland}

In Queensland, formed as a separate colony from New South Wales in June 1859, there were two inquiries involving Aboriginal policy during the first two years of responsible government, both primarily to do with the same issues concerning the Native Mounted Police that had preoccupied the two earlier inquiries. From them we gain a strong sense of the depth of pastoralists' concern with the strength of Aboriginal resistance and how to respond to it; we also learn of some competing views and considerations. Both inquiries emanated from and reported to a parliament dominated by pastoralists, distinctly conservative and protective of property rights. The government did not institute universal manhood suffrage for the Assembly until 1872; the first liberal government was elected in 1877 .

The first inquiry was a Select Committee to the Legislative Assembly on the Queensland police force, whose report was tabled in parliament in September 1860. The inquiry seems to have been prompted by general debates about recruitments, cohesiveness and dismissals within the police force as a whole, with some specific concerns raised about the costs of running the Native Mounted Police. Frontier violence was never far from the public consciousness, though, particularly following the murder of the crew of the Sapphire by Indigenous people in the Torres Strait earlier that year. ${ }^{39}$ The resulting report had two parts: one on the administration of the regular police, and the other on the NMP. The latter concluded that the NMP, while costly to operate, remained necessary. The newly responsible government of Queensland reaffirmed its support for this force, while at the same time the language of the report made clear that the NMP were seen as a 'frontier presence', with all the hints of illegality, wildness and distance that this implied. The report recommended that the NMP receive better supplies and clerical assistance, and that the force increase as 'new country becomes occupied', with Aboriginal troopers procured from far away districts, to keep them under the control of their white officers. When the report was tabled in the Legislative Assembly, there appears to have been little debate about it, apart from some disagreement over who should appoint the white officers. The Colonial Secretary remarked with some pride that backing for the NMP would become more efficient now that Queenslanders had their own government, and reiterated the importance of retaining a police force in districts like Gladstone,

39 Lesley McGregor, 'The Police Department 1859-1914', in Kay Cohen and Kenneth Wiltshire (eds), People, Places and Policies: Aspects of Queensland Government Administration 1859-1920, University of Queensland Press, St Lucia, 1995: 60-69; Moreton Bay Courier, 27 March 1860: 2, and 23 June 1860: 2. 
where 'the blacks were numerous and daring' and where the government was still selling tens of thousands of pounds worth of land. The Assembly adopted the report without opposition. ${ }^{40}$

Only six months later, the Native Police force was again under parliamentary scrutiny, and this time the accusations were more serious. On 1 May 1861, Robert Mackenzie, a pastoralist and colonial Treasurer, moved in the Assembly for a Select Committee to inquire into the organisation and management of the force. Mackenzie's motion appears to have been prompted, at least in part, by a paid advertisement placed in the Moreton Bay Courier by John Mortimer, a squatter relatively sympathetic to Aboriginal people, alleging murderous behaviour by the Native Police on and around his station, Manumbar. ${ }^{41}$ At around the same time, Dr Henry Challinor, the coroner investigating the deaths of three Indigenous people on a property at Fassifern, south-west of Brisbane, had reported to the Attorney-General that they had died at the hands of the Native Police, with the pastoralist and local police magistrate clearly implicated. When the Attorney-General refused to lay blame, Challinor, like Mortimer, had given information to the Courier. ${ }^{42}$ There were, in fact, four separate incidents, including those at Manumbar and Fassifern, for the committee to investigate. The Assembly broadened the committee's terms of reference beyond the NMP, and asked it to inquire into 'how far it may be practicable to ameliorate the present condition of the Aborigines of this Colony'. ${ }^{43}$ The committee was controversial from the beginning, composed as it was only of men who supported the Native Police force and opposed attempts to protect and support Aboriginal people. ${ }^{44}$ Of the seven members of the committee, five including Mackenzie, the chair, were pastoralists, one was a farmer and station manager, and one had a son in the Native Police. Two members owned stations in the area where the incidents under question had taken place. Significantly, Challinor, a member of parliament, was not included. So weighted was the committee in favour of the Native Police and against Aboriginal interests, that several witnesses in protest refused to appear before it. The committee, however, did interview a variety of

\footnotetext{
40 Moreton Bay Courier, 8 September 1860: 3, 6; 'Queensland: Final Report from the Select Committee on Police', 5 September 1860, in Queensland: Votes and Proceedings of the Legislative Assembly, TP Pugh, Brisbane, 1860: 534-565.

41 Moreton Bay Courier, 16 March 1861: 3; Denis Cryle, The Press in Colonial Queensland: A Social and Political History, 1845-1875, University of Queensland Press, St Lucia, 1989: 67-68; Malcolm D Prentis, 'John Mortimer of Manumbar and the 1861 Native Police Inquiry in Queensland', Journal of the Royal Historical Society of Queensland, 14, May 1992: 466-480, this point on p. 474.

42 Rosalind Kidd, The Way We Civilise: Aboriginal Affairs, the Untold Story, University of Queensland Press, St Lucia, 1997: 13.

43 'Report from the Select Committee on the Native Police Force and the Condition of the Aborigines Generally; together with the proceedings of the committee and the minutes of evidence', ordered to be printed on 17 July 1861, Queensland Votes and Proceedings of the Legislative Assembly, 1861. http://www.nla.gov. au/apps/doview/nla.aus-vn529131-p.pdf.

44 See the report from Brisbane correspondent, The Argus, 8 August, 1861: 5, reprinted in the Hobart Mercury, 13 August 1861: 3; Prentis, 'John Mortimer': 474-475.
} 
witnesses, including Challinor, and several others with concerns about Native Police treatment of Aboriginal people, though, as Malcolm Prentis puts it, the chair's questioning of Challinor and Mortimer was 'quite aggressive and pedantic'. ${ }^{45}$

By far the largest part of the report tabled in parliament on 17 July 1861 dealt with the Native Police. It found that some of the allegations of murderous and illegal behaviour by the NMP were justified, but saw these as the actions of a few and not representative of the force as a whole. It recommended some changes to methods of recruitment, management, and discipline. The Brisbane Courier (the paper had recently changed its name from the Moreton Bay Courier) was appalled at the committee's findings; we should not, it wrote, 'protect aggression, and violence, and murder'. ${ }^{46}$

While the committee focused on the question of the Native Police, it did also address the more general question of the condition of the Aborigines. Its report was harsh indeed on the nature of Aboriginal people and their chances of 'civilisation'. It advised that the evidence taken by the committee 'shews beyond doubt that all attempts to Christianize or educate the aborigines of Australia have hitherto proved abortive', on the grounds that despite education, 'the Natives of both sexes invariably return to their savage habits'. The report went on to say that they were 'addicted to cannibalism', had 'no idea of a future state', and are 'sunk in the lowest depths of barbarism'. Missions and schools in the different colonies had 'but partial success' ${ }^{47}$ Its only recommendation for action to improve their social condition was to establish, on the recommendation of Johann Zillman, former Lutheran missionary and now farmer still actively involved in church activity, a Missionary Cotton Company. The government would supply it land and other assistance, and in return, it would seek to educate the children and employ the parents in cotton growing. ${ }^{48}$ There was no recommendation for the formation of the office of Protector on Victorian or South Australian lines, despite Challinor's suggestion in his evidence that they ought to do so, and no suggestion of support for missionary or other educational endeavour. The Assembly adopted the report, though there was no enthusiasm for the suggestion for a Missionary Cotton Company. The question of both child and adult labour was, however, to recur through the following decade; another government inquiry addressed it in 1874, tellingly asked to 'inquire what can be done to ameliorate the condition of aborigines and to make them more useful' ${ }^{49}$

45 Prentis, 'John Mortimer': 475.

46 Brisbane Courier, 27 July 1861: 2; Cryle, The Press in Colonial Queensland: 67.

47 'Report from the Select Committee on the Native Police Force', 17 July 1861: 4.

48 'Report from the Select Committee on the Native Police Force', 17 July 1861: 5.

49 Kidd, The Way We Civilise: 25. 
It is worth noting, however, that there were dissenting voices against the committee's report. The Brisbane Courier, for example, commented angrily on the section dealing with the condition of the Aborigines, suggesting that the committee members were ignorant and might learn from the great orators on the question of African slavery, such as Burke and Wilberforce, before again entering into 'discussions on the nature of the savage, or the means for his civilisation' ${ }^{50}$ Despite this dissent, the government continued to work in the spirit of the report, on the one hand funding and maintaining the NMP, which continued its task of quelling Aboriginal resistance often with little regard for Aboriginal life, and on the other excusing itself from virtually any responsibility for Aboriginal protection and welfare. There was in some areas an annual blanket distribution, and a few pockets of land were reserved for missions in the southern region of the colony, but that was all. ${ }^{51}$

Only three months after the committee tabled its report, reports of the murders by Aboriginal people of 19 members of the Wills party at Cullin-la-Ringo, near Springsure, rocked the colony. As one historian of the Native Police, Jonathon Richards, puts it, 'If the Hornet Bank reprisals were bad, those that followed the Cullin-la-ringo episode were worse' ${ }^{52}$ Despite evidence of provocation by the abduction of two boys, settlers saw Indigenous people as murderous and never to be trusted, and a major killing spree ensued. ${ }^{53}$

\section{Tasmania and Western Australia}

For very different reasons, neither Tasmania nor Western Australia at this time produced parliamentary reports on questions of Aboriginal policy. In Tasmania, the most common assumption was that Aboriginal policy would soon be a thing of the past, while in Western Australia there was as yet no parliamentary system. In both colonies, however, governments continued to shape some form of Aboriginal policy.

In Tasmania, the institution of self-government in 1855 meant a slashing of the budget for the remaining Aboriginal population at Oyster Cove. ${ }^{54}$ While it continued the annuity awarded to Fanny Cochrane Smith on her marriage to a local colonist, William Smith, the previous year and in 1857 granted her land

\footnotetext{
50 Brisbane Courier, 27 July 1861: 2.

51 Kidd, The Way We Civilise: 14.

52 Jonathan Richards, The Secret War: A True History of Queensland's Native Police, University of Queensland Press, St Lucia, 2008: 23.

53 See also Henry Reynolds, Frontier: Aborigines, Settlers, and Land, Allen \& Unwin, Sydney: 48-49.

54 Anna Haebich, Broken Circles: Fragmenting Indigenous Families, 1800-2000, Fremantle Arts Centre Press, Fremantle, 2000: 124 .
} 
at Nicolls Rivulet, near Oyster Cove, ${ }^{55}$ the overall picture was extremely dire for Aboriginal people. By 1859, the population at the Aboriginal settlement at Oyster Cove consisted of a mere 14 people. Many colonists were simply waiting for them to die; as senior civil servant Hugh Munro Hull wrote in his wellknown almanac in 1859, The Royal Kalendar and Guide to Tasmania, 'the race is fast falling away and its utter extinction will be hardly regretted'. ${ }^{56}$ There was no call for inquiries or select committees, and the Tasmanian colonial government seems to have effectively abandoned the community.

Over the next two decades, as the remaining population at Oyster Cove died away and no children were born, the idea that Tasmanian Aboriginal people were fast becoming extinct took hold. Nevertheless, a new community was growing in the Furneaux islands of Bass Strait, descended from the Indigenous women and white sealers. The colonial government continued to accept some responsibility for particular women in this community, for example by continuing to pay pensions granted by earlier administrations. ${ }^{57}$ The islanders pressed claims for education and secure leases of land that in part rested on their being the descendants of Aboriginal people. In their campaigns, they enlisted the support of clergymen from the Church of England, several of whom became important allies. ${ }^{58}$ One of them, the Bishop of Tasmania, Francis Russell Nixon, published his impressions of the islanders in his book, Cruise of the Beacon (1857), portraying them as vigorous, intelligent 'half-castes' needing missionary and state intervention. ${ }^{59}$

Nixon's agitation for state support for education of the islanders was, however, unsuccessful, and their campaign continued into the 1860s. Their local member, James Grant, made speeches in parliament criticising government neglect, which was depriving the people of the islands of education and forcing them off their land. In one such speech in October 1861, Grant acknowledged that many of the islanders were 'descendants of the aborigines' who 'had a claim on our sympathies'. ${ }^{60}$ Parliament supported his call the following September for an educational fund for the islanders, though only on the condition that

\footnotetext{
55 J Clark, 'Smith, Fanny Cochrane (1834-1905)', Australian Dictionary of Biography, The Australian National University, 1988, http://adb.anu.edu.au/biography/smith-fanny-cochrane-8466.

56 Hugh Munro Hull, The Royal Kalendar and Guide to Tasmania for 1859, William Fletcher, Hobart Town, 1859: 20. Quoted in Lyndall Ryan, Tasmanian Aborigines: A History since 1803, Allen \& Unwin, Sydney, 2012: 262 .

57 Tasmania, Legislative Council, 'Half-Caste Islanders in Bass's Straits: Report of the Ven. Archdeacon Reibey', printed 26 August 1863, in Journals of the Legislative Council (with papers), vol. IX, James Barnard, Hobart, 1863.

58 James Boyce, God's Own Country? The Anglican Church and Tasmanian Aborigines, Anglicare, Hobart, 2001: 50; Lyndall Ryan, The Aboriginal Tasmanians, Allen \& Unwin, Sydney, 1994: 225.

59 Francis Russell Nixon, Cruise of the Beacon: A Narrative of a Visit to the Islands in Bass's Straits, Bell \& Daldy, London, 1857: 43-47.

60 Mercury, 3 October 1861: 2, 12 October 1861: 3.
} 
an equivalent sum be raised through private charity. ${ }^{61}$ In doing so, it was influenced by the prevailing colonial discourse that acknowledged Indigenous dispossession as a debt but not necessarily an injustice, and that could recognise the ancestry but not the ongoing cultural identity of the Bass Strait community. Furthermore, the long-standing reputation of the islands as marginal places populated by supposedly criminal white men and Indigenous women, helped foster a sense that this could be a place for Christian charity. Eventually, in 1871, in response to continuing pressure from the islanders, the government appointed a schoolteacher to Badger Island, offered the residents a block on Cape Barren Island, and gazetted Chappell and Big Dog islands as mutton bird rookeries under the Game Preservation Act 1871 (Tas). ${ }^{62}$ As a result, the move by the islander mixed-race population onto Cape Barren Island intensified through the 1870s, and in 1881 the government reserved 6,000 acres of land there for their use. ${ }^{63}$

In Western Australia, the lack of a parliamentary report on Aboriginal matters at this time occurred for very different reasons. In the huge territory to the west, the greater part of which was at this time still occupied by Aboriginal people rather than settlers, responsible government had not yet arrived. Government was through a British-appointed governor responsible to the Colonial Office, supported by appointed officials and a nominated and advisory Legislative Council. The settler population in 1859 was still less than 15,000, not large enough in British eyes to warrant self-government. ${ }^{64}$ Furthermore, Western Australia had begun accepting convicts in 1850, and it was not until convict transportation finally ended in 1868 that it gained, in 1870, a part-nominated, part-elected Legislative Council of the kind the other colonies had had until the mid-1850s. In this situation, then, the select committees that occurred in the selfgoverning colonies apart from Tasmania could not occur in Western Australia, and there was no major inquiry involving the Legislative Council until 1884. During the 1850s and 1860s, British officials withdrew funding and support for protection policies, and focused on the operations of the law, punishment and imprisonment to manage both frontier conflict and labour relations. ${ }^{65}$

The cause of protection was at a low ebb. When Britain cut off direct funding for the Protector in Western Australia, British officials in the colony did not

\footnotetext{
61 Mercury, 19 September 1862: 5; Tasmania, Legislative Council, 'Half-Caste Islanders in Bass's Straits'.

62 Ryan, The Aboriginal Tasmanians: 223-227.

63 Kristyn Harman, 'Protecting Tasmanian Aborigines: American and Queensland influences on the Cape Barren Island Reserve Act, 1912', The Journal of Imperial and Commonwealth History 41(5): 747; see also Tasmanian Government Gazette, 15 March 1881.

64 ABS, Australian Historical Population Statistics, Table 1. The Indigenous population was three times this figure, ABS, Australian Historical Population Statistics, Table 8.

65 Paul Hasluck, Black Australians: A Survey of Native Policy in Western Australia 1829-1897, Melbourne University Press, Melbourne, 1970 [1942]: 79.
} 
arrange for the colony to step in, and the role of Protector was at first combined with other tasks and then in 1857 allowed to lapse altogether. ${ }^{66}$ There were no lands reserved for Aboriginal use until 1878. ${ }^{67}$

Missionary and educational activity owed little to government support during the 1850s. George King's Freemantle school closed in 1851, and John Smithies' Methodist institution, established in the early 1840s in Perth, closed in 1855 after two moves westward in an effort to get away from settler influence. ${ }^{68}$ The government did support a small school for Aboriginal children in Albany, south of Perth, run by Mrs Camfield, without remuneration, from 1852, its numbers rising to 18 in 1858, but this was small-scale education indeed. ${ }^{69}$ Moreover, the government could take little credit for the one successful mission of this period, the Benedictine Catholic mission at New Norcia, 132 kilometres north of Perth. Having begun in 1846 with support from Rome, then been suspended from 1849 to 1853 while its leader, Father Salvado, sought greater financial support in Europe, the mission gained a firmer footing in 1853 when Salvado returned with a further three priests and 37 lay brothers, laying the foundation for its considerable longer-term success. From 1859, the government did support the mission with funding of $£ 100$ per year, but the overwhelming picture, nevertheless, is one of little government interest in protection, education, and 'civilisation'. The main measure of control continued to be through the law, punishment, and imprisonment; it is worth noting, though, as Mark Finnane and John Maguire point out, that imprisonment carried with it in the early stages at least some notion of imparting civilisation. ${ }^{70}$ Rottnest Island, established as an Aboriginal prison in 1840 but closed in 1849, was re-established in 1855, and became a prime site for Aboriginal punishment for many decades.

Western Australia's difference from the other colonies highlights something a little unexpected; there was more government interest in Aboriginal management and in some cases protection in some of the newly self-governing colonies than in the only one that Britain continued to govern directly. The protectionist impulse of the 1840s survived better in the rapidly expanding colonies of Victoria and South Australia, with their more liberal politics, than in conservative Western Australia with its tiny settler population and exclusive focus on economic development. On the other hand, the difference between Western Australia and Queensland in the management of frontier conflict is striking. Where Queensland relied on the Native Police force to 'disperse' Aboriginal people resisting settlement, with significant injury and loss of life, Western Australia saw the extensive use of the law - arrest, trial and imprisonment - in an attempt

66 Hasluck, Black Australians: 80.

67 WA Government Gazette, 18 June 1878: 145 and 6 August 1878: 6, quoted in Hasluck, Black Australians: 114.

68 Hasluck, Black Australians: 89-92.

69 Hasluck, Black Australians: 93-94.

70 Finnane and Maguire, 'The uses of punishment and exile': 285-286. 
to achieve a similar object without loss of life. As settlement spread, however, the use of the law came to be increasingly oppressive, as the government gave pastoralists in the role of magistrates legal powers that they often abused, and Aboriginal people were made to walk vast distances, often connected by chains including neck chains, to places of trial and punishment. Nevertheless, Western Australia did not witness to the same extent the killing fields that characterised large parts of Queensland.

\section{Conclusion}

Victoria was different. While the first decade of responsible government produced debate about the future of Aboriginal policy in (almost) all the colonies, the focus and tone were distinctive to each one. The debate over how to best defeat Aboriginal resistance that was so important in Queensland, Western Australia and South Australia in the second half of the nineteenth century was no longer relevant in Victoria when McCombie called for his Select Committee. Nor did Victoria share to any great extent those three colonies' concern with the control of Aboriginal labour. On the other hand, the laissez faire thinking based on the idea that Aboriginal people were unable to be 'improved' and that they were fast disappearing was less evident in Victoria than in New South Wales and Tasmania. In Victoria more than anywhere else except possibly South Australia, a form of humanitarianism survived that, at one end, was concerned with protection and education and, at the other, with stricter management and control of Aboriginal people within a new colonial order.

There are, we think, several reasons for this distinctiveness. They include the early end of the frontier after the rapid invasion and dispossession of the period from 1835 to 1855 , and the lingering influence of the Protectorate of the 1840s. Also important are the rapid rise of a new, scientific, metropolitan culture in the 1850s, and the role of some key figures like Thomas McCombie.

Indigenous agency also played an important part. Loyal addresses and petitions were much more common in Victoria than the other colonies, and although policymakers did not often acknowledge it officially, the propensity of Aboriginal Victorians to place direct pressure on the authorities both helped prompt, and was strengthened by, the Victorian tradition of protection and establishing managed reserves. The Aboriginal men who in their demands for land pressed William Thomas in 1859 and the Central Board in 1860, and who passed on a loyal address to Queen Victoria in 1863, were all helping shape the relationships that emerged in those years. They were not alone in doing so, as the petitions at Flinders Island in the 1840s, and in New South Wales in the 1880s attest, but 
the tradition was especially strong in Victoria. ${ }^{71}$ Perhaps ironically, it would also lead Victorian Indigenous people to voice some particularly passionate criticisms of the 'protection' model, as the many histories of the Coranderrk mission, for example, have traced. The resulting climate of bureaucracy, ethnography and activism produced a history for Indigenous Victorians that was complex, articulate and heavily (if unevenly) documented - a combination that scholars and storytellers continue to find irresistible.

71 Ann Curthoys and Jessie Mitchell, “'Bring this Paper to the good Governor": Aboriginal petitioning in Britain's Australian colonies' in Saliha Belmessous (ed.), Native Claims: Indigenous Law against Empire 1500-1920, Oxford University Press, New York, 2011: 182-203. 
This text is taken from Settler Colonial Governance in Nineteenth-Century Victoria, edited by Leigh Boucher and Lynette Russell, published 2015 by ANU Press and Aboriginal History Inc., The Australian National University, Canberra, Australia. 